\title{
Evaluation of Nutrient Index to Assess Soil Fertility in The South East El- Qantara, North Sinai
}

\author{
M. F. Abou Yuossef ${ }^{1}$, M. E. Husein ${ }^{2}$ and Amal L. Abd EL- Latif2 \\ ${ }^{I}$ Soil Conservation Dept., Desert Research Center and ${ }^{2}$ Soil \\ Dept., Fac. of Agriculture, Cairo University, Cairo, Egypt
}

\begin{abstract}
7 HE GOVERNMENTAL plan aims for reclamation and cultivation of about 400,000 feddans concentrated mainly in ElTina Plain (50,000 feddans), South East El-Qantara (75,000 feddans), Rabaa (70,000 feddans), Bir El-Abd (70,000 feddans) and El-Ser and El-Qawarir (135,000 feddans) areas.. The present study revealed that there is no much variation in soil fertility status of soils developed on various landforms in the studied area as the soils have low to medium organic carbon ( 0.14 to $1.20 \%$ ), low available nitrogen (4.19 to 46.70 $\mathrm{mg} / \mathrm{kg}$ ); low to high available P (4.11 to $59.23 \mathrm{mg} / \mathrm{kg}$ ) and deficient to adequate available $\mathrm{K}(34.00$ to $-825 \mathrm{mg} / \mathrm{kg})$ contents. The soils of South East El-Qantara were categorized according to nutrient index into medium-low-medium-low (MLML) category based on OC, available $\mathrm{N}$, available $\mathrm{P}$ and available $\mathrm{K}$ concentrations, respectively.
\end{abstract}

Keywords: Nutrient index, Evaluation, Soil Fertility, North Sinai

From the advent of agriculture, there has been an innate interest in soil and land quality (Carter et al., 2004) and understanding changes in soil fertility resulting from agricultural intensification before they severely limit crop yields. Historically, few farmers used chemicals, but maintained soil fertility by allowing long fallow periods. Today, farmers have increased the use of chemical fertilizers and herbicides, and fallow cycles have decreased or disappeared, with the continuous use of the land becoming more frequent (Zhang and Zhang, 2007). Frequently, loss of productivity has been related to the loss of soil organic matter (SOM) and stored nutrients that result from cultivation (Juo and Manu, 1996). Hence, an understanding of the distributions of soil properties at the field scale is important for refining agricultural management practices and assessing the effects of agriculture on environmental quality (Cambardella et al., 1994). Evaluating agricultural land management practices requires knowledge of soil spatial variability and understanding their relationships because of the fact that (a) spatial variability in soils occurs naturally from pedogenic factors, (b) natural variability of soil results from complex interactions between geology, topography, climate as well as soil use (Jenny, 1980 and Quine \& Zahng, 2002). In addition, variability can also occur as a result of land use and management strategies, making the soil to exhibit marked spatial variability at the macro- and micro- scale (Brejda et al., 2000 and Vieira \& Paz-Gonzalez, 2003). 
Karlen et al. (1997) proposed a complete definition for soil quality as "the capacity of a specific kind of soil to function, within natural or managed ecosystem boundaries, to sustain biological productivity, maintain or enhance water and air quality, and promote human heath". But, the general consensus is that the soil quality concept should not be limited to soil productivity, but should encompass environmental quality (Karlen et al., 2003). Large quantities of mineral nutrients are removed from soils due to growth and development of plant and harvesting of crops. Hence, maintaining or improving soil quality can provide economic benefits in the form of increased productivity, more efficient use of nutrients and pesticides, improvements in water and air quality, and lessening of greenhouse gas emissions (USDA-ERS, 1997). Thus, assessment of soil quality involves measuring physical, chemical, and biological soil properties and using these measured values to detect changes in soil as a result of land use change or management practices (Adolfo et al., 2007). Though the soil fertility, compactability and erodability are the elements of soil quality, the problem of decline in soil fertility endangers the maximum the growth in productivity (Katyal, 2003). Warren and Agnew (1988) opined that of all the threats to sustainability, the threat due to soil fertility depletion is the most serious. Depending upon the cropping pattern, leaching, erosion, etc., soil looses a considerable amount of nutrients every year. If cropping is continued over a period of time without nutrients being restored to the soil, its fertility will be reduced and crop yields will decline. Poor soil fertility conceives sparse plant cover, which promote erosion vulnerability. This happens because $90 \%$ of plant available $\mathrm{N}$ and S, $50-60 \% \mathrm{~K}, 25-30 \% \mathrm{P}$ and almost $70 \%$ of micronutrients reside in organic matter (Stevenson, 1982).

Soil fertility fluctuates throughout the growing season each year due to alteration in the quantity and availability of mineral nutrients by the addition of fertilizers, manure, compost, mulch, and lime or sulfur, in addition to leaching. Hence, soil testing will determine the current fertility status and provides information regarding nutrient availability in soils which forms the basis for the fertilizer recommendations for maximizing crop yields and further to maintain the optimum fertility in soil year after year.

The soils in North Sinai will be provided with water through El-Salam Canal, which will pass below the Suez Canal. The Governmental plan aims for the reclamation and cultivation of about 400.000 feddans concentrated mainly in ElTina Plain (50.000 feddans), South East El-Qantara (75.00 feddans), Rabaa (70.000 feddans), Bir El-Abd (70.000 feddans) and El-Ser and El-Qawarir (135.000 feddans) areas.

Area of the investigations

South East El-Qantara is located in the north western corner of Sinai Peninsula between latitudes $30^{\circ} 50$, and $31^{\circ} 05, \mathrm{~N}$, and longitudes $32^{\circ} 20$, and $32^{\circ}$

Egypt. J. Soil Sci. 56, No.3 (2016) 
40'E. It has a triangular shape with one side about $40 \mathrm{~km}$ long running along the Suez Canal and another side of $35 \mathrm{~km}$ along the coast. The soils vary from sand to clay texture and extremely saline. Soil colour ranges from light gray to olive (dry) and greyish brown to gray (moist). Soil structure varies from single grains to strong or moderate, coarse to medium, angular to subangular blocky. The pedological features identified within profiles depth are accumulation of gypsum crystals, common salt crystals and few lime concretions.

\section{Materials and Methodology}

The analyzed soil samples have been collected from South East El-Qantara. The landscape is almost flat. Soil parent material is a mixture of alluvium sediments, originated from old Nile branches and lacustrine deposits, and is sometimes contaminated with aecolian sand sediments. The area is barren from plant cover. Some patches are covered with some species of Halophytes. Water table in some cases is very shallow.

\section{Selection of representative soil series}

In order to study the background levels of nutrient index to asses' soil fertility in South East El-Qantara soils, 97 representative soils were selected from representative 12 soil groups. Soil samples representing the morphological variations throughout the entire depths of each profile were collected. Soil sampling was replicated three times at the different layers for every profile.

\section{Analytical procedures}

-Particle size distribution was carried out according to Klute (1986).

-The water extract components were determined in the soil paste extract, using the standard methods of analysis as described by Page et al. (1982).

-Organic carbon was determined following by the modified method by Page et al (1982).

-Available $\mathrm{N}$ in soil samples was chemically extracted by $2 \mathrm{M} \mathrm{KCl}$ solution and determind according to Dhank and Johson (1990).

-Available P in soil samples was extracted by $0.5 M \mathrm{NaHCO}_{3}, \mathrm{pH} 8.5$ solution and determined according to Page et al. (1982).

-Available $\mathrm{K}$ was extracted by ammonium acetate $\mathrm{pH} 7.0$ and determined flamephotometry.

-Available micronutrients ( $\mathrm{Fe}, \mathrm{Mn}, \mathrm{Zn}$, and $\mathrm{Cu}$ ) in soil samples were extracted using DTPA solution according to Lindsay and Norvell (1978) and measured using Flame Atomic Absorption Spectrophotometer (Page et al., 1982).

Physical and chemical characteristics of the studied samples are given in Table 1. 
TABLE 1. Some chemical and physical characteristics of the studied soil

\begin{tabular}{|c|c|c|c|c|}
\hline Sample No. & $\begin{array}{c}\text { O.M } \\
\%\end{array}$ & pH & $\begin{array}{c}\begin{array}{c}E C \\
(d S / m)\end{array} \\
\end{array}$ & Texture Class \\
\hline 1 & 0.76 & 8.81 & 7.30 & clay \\
\hline 2 & 1.05 & 8.64 & 4.49 & clay \\
\hline 3 & 0.72 & 8.61 & 1.97 & sandy clay loam \\
\hline 4 & 0.49 & 8.47 & 0.65 & sandy loam \\
\hline 5 & 0.65 & 8.69 & 5.34 & silty loam \\
\hline 6 & 1.2 & 8.55 & 2.50 & clay \\
\hline 7 & 0.58 & 8.49 & 2.50 & sandy loam \\
\hline 8 & 0.6 & 8.19 & 2.04 & sandy clay \\
\hline 9 & 0.72 & 8.36 & 1.93 & sandy clay loam \\
\hline 10 & 0.69 & 8.45 & 2.65 & clay loam \\
\hline 11 & 0.14 & 8.55 & 3.36 & clay \\
\hline 12 & 1.01 & 8.34 & 3.58 & clay \\
\hline 13 & 1.01 & 8.19 & 3.79 & silty loam \\
\hline 14 & 0.72 & 8.78 & 15.22 & clay \\
\hline 15 & 0.86 & 8.04 & 4.75 & clay \\
\hline 16 & 0.86 & 8.52 & 7.95 & clay \\
\hline 17 & 1.1 & 8.6 & 10.56 & clay \\
\hline 18 & 0.68 & 8.33 & 1.46 & sandy \\
\hline 19 & 1.01 & 8.12 & 1.70 & sandy loam \\
\hline 20 & 1.1 & 8.27 & 1.62 & sandy \\
\hline 21 & 1.02 & 8.32 & 1.617 & sandy \\
\hline 22 & 0.86 & 8.18 & 1.99 & sandy loam \\
\hline 23 & 0.43 & 8.32 & 1.79 & sandy \\
\hline 24 & 0.47 & 8.17 & 1.58 & sandy \\
\hline 25 & 0.33 & 8.24 & 1.912 & sandy \\
\hline
\end{tabular}

Egypt. J. Soil Sci. 56, No.3 (2016) 
TABLE 1. Cont.

\begin{tabular}{|c|c|c|c|c|}
\hline Sample No. & $\begin{array}{c}\text { O.M } \\
\%\end{array}$ & pH & $\begin{array}{c}\begin{array}{c}\mathrm{EC} \\
(\mathrm{dS} / \mathrm{m})\end{array} \\
\end{array}$ & Texture Class \\
\hline 26 & 1.01 & 8.34 & 1.59 & sandy \\
\hline 27 & 0.76 & 8.22 & 1.90 & sandy \\
\hline 28 & 0.91 & 8.01 & 1.82 & sandy loam \\
\hline 29 & 0.53 & 8.13 & 1.74 & sandy loam \\
\hline 30 & 0.64 & 8.15 & 2.97 & sandy \\
\hline 31 & 0.95 & 8.02 & 1.95 & sandy \\
\hline 32 & 0.96 & 7.81 & 1.75 & loamy sand \\
\hline 33 & 0.72 & 8.28 & 1.75 & sandy \\
\hline 34 & 1.01 & 7.91 & 6.87 & loamy sand \\
\hline 35 & 1.1 & 8.25 & 1.96 & sandy loam \\
\hline 36 & 0.75 & 8.38 & 3.94 & sandy \\
\hline 37 & 0.82 & 8.34 & 1.76 & loamy sand \\
\hline 38 & 0.84 & 8.45 & 1.54 & sandy \\
\hline 39 & 0.9 & 8.07 & 2.87 & sandy loam \\
\hline 40 & 0.93 & 8.10 & 1.95 & sandy loam \\
\hline 41 & 0.33 & 8.06 & 2.34 & loamy \\
\hline 42 & 0.28 & 8.09 & 2.16 & sandy loam \\
\hline 43 & 0.62 & 8.10 & 1.80 & sandy \\
\hline 44 & 0.63 & 8.09 & 1.55 & loamy sand \\
\hline 45 & 0.34 & 8.02 & 1.77 & loamy sand \\
\hline 46 & 0.76 & 8.09 & 1.61 & loamy sand \\
\hline 47 & 0.72 & 8.00 & 1.97 & loamy sand \\
\hline 48 & 0.75 & 8.08 & 2.09 & sandy \\
\hline 49 & 0.7 & 7.91 & 1.77 & sandy \\
\hline 50 & 0.76 & 8.06 & 4.02 & sandy \\
\hline
\end{tabular}

Egypt. J. Soil Sci. 56, No. 3 (2016) 
TABLE 1.Cont.

\begin{tabular}{|c|c|c|c|c|}
\hline Sample No. & $\begin{array}{c}\text { OM } \\
\% \\
\end{array}$ & pH & $\begin{array}{c}\mathrm{EC} \\
(\mathrm{dS} / \mathrm{m}) \\
\end{array}$ & Texture Class \\
\hline 51 & 0.71 & 8.06 & 2.02 & sandy clay \\
\hline 52 & 0.83 & 8.04 & 2.14 & loamy sand \\
\hline 53 & 0.75 & 8.13 & 1.92 & sandy loam \\
\hline 54 & 0.76 & 8.09 & 2.50 & clay loam \\
\hline 55 & 0.52 & 8.11 & 3.57 & clay \\
\hline 56 & 0.73 & 8.17 & 4.23 & sandy loam \\
\hline 57 & 0.64 & 8.29 & 2.29 & silty loam \\
\hline 58 & 0.37 & 8.04 & 2.60 & sandy loam \\
\hline 59 & 0.83 & 8.35 & 1.58 & loamy sand \\
\hline 60 & 0.57 & 8.02 & 1.79 & loamy \\
\hline 61 & 0.64 & 8.37 & 1.91 & sandy loam \\
\hline 62 & 0.78 & 8.40 & 1.86 & sandy loam \\
\hline 63 & 0.73 & 8.36 & 1.79 & sandy loam \\
\hline 64 & 0.82 & 8.33 & 1.80 & clay loam \\
\hline 65 & 0.66 & 8.25 & 3.42 & clay loam \\
\hline 66 & 0.74 & 8.35 & 2.57 & sandy loam \\
\hline 67 & 0.86 & 8.26 & 1.76 & sandy loam \\
\hline 68 & 0.47 & 8.33 & 2.09 & loamy sand \\
\hline 69 & 0.52 & 8.27 & 1.62 & sandy \\
\hline 70 & 0.57 & 8.28 & 1.78 & sandy \\
\hline 71 & 0.57 & 8.23 & 1.56 & sandy \\
\hline 72 & 0.64 & 8.24 & 1.61 & loamy sand \\
\hline 73 & 0.43 & 8.32 & 1.66 & sandy \\
\hline 74 & 0.76 & 7.92 & 1.57 & sandy \\
\hline 75 & 0.85 & 8.15 & 3.87 & silty loam \\
\hline
\end{tabular}

Egypt. J. Soil Sci. 56, No.3 (2016) 
TABLE 1. Cont.

\begin{tabular}{|c|c|c|c|c|}
\hline Sample No. & $\begin{array}{c}\text { OM } \\
\%\end{array}$ & pH & $\begin{array}{c}\begin{array}{c}E C \\
(\mathrm{dS} / \mathrm{m})\end{array} \\
\end{array}$ & Texture Class \\
\hline 76 & 0.58 & 7.87 & 1.57 & sandy \\
\hline 77 & 0.73 & 7.98 & 1.21 & sandy loam \\
\hline 78 & 0.54 & 7.82 & 1.62 & sandy \\
\hline 79 & 0.56 & 7.84 & 1.67 & sandy \\
\hline 80 & 0.73 & 8.07 & 1.29 & sandy \\
\hline 81 & 0.74 & 8.07 & 1.26 & sandy \\
\hline 82 & 0.87 & 7.42 & 1.42 & sandy \\
\hline 83 & 0.6 & 7.82 & 1.24 & sandy \\
\hline 84 & 0.32 & 7.53 & 1.61 & sandy \\
\hline 85 & 0.47 & 8.07 & 1.24 & sandy \\
\hline 86 & 0.49 & 8.05 & 1.25 & sandy \\
\hline 87 & 0.56 & 8.16 & 1.17 & sandy loam \\
\hline 88 & 0.44 & 7.73 & 1.37 & sandy \\
\hline 89 & 0.49 & 7.84 & 1.59 & sandy \\
\hline 90 & 0.51 & 8.2 & 1.39 & sandy \\
\hline 91 & 0.42 & 8.00 & 2.77 & sandy \\
\hline 92 & 0.38 & 8.01 & 1.25 & sandy \\
\hline 93 & 0.29 & 7.72 & 1.40 & sandy loam \\
\hline 94 & 0.42 & 8.10 & 1.21 & sandy \\
\hline 95 & 0.42 & 8.15 & 2.88 & sandy \\
\hline 96 & 0.47 & 8.31 & 1.24 & sandy \\
\hline 97 & 0.35 & 8.01 & 2.23 & sandy \\
\hline
\end{tabular}




\section{Results and Discussion}

\section{Soil texture}

The studied soil samples varied widely in their texture classes, represented by 12 soil groups (Fig. 1).The texture varied from Sandy (42.3\%, 41 soil), loamy sand $(11.3 \%, 11$ soil), sandy loam $(21.7 \%, 21$ soil), sand clay loam $(2.1 \%, 2$ soil), loamy $(2.1 \%, 2$ soil), clay loam $(4.1 \%, 4$ soil), silty loam $(4.1 \%, 4$ soil $)$, sand clay $(2.1 \%, 2$ soil $)$, to clay $(10.3 \%, 10$ soil $)$

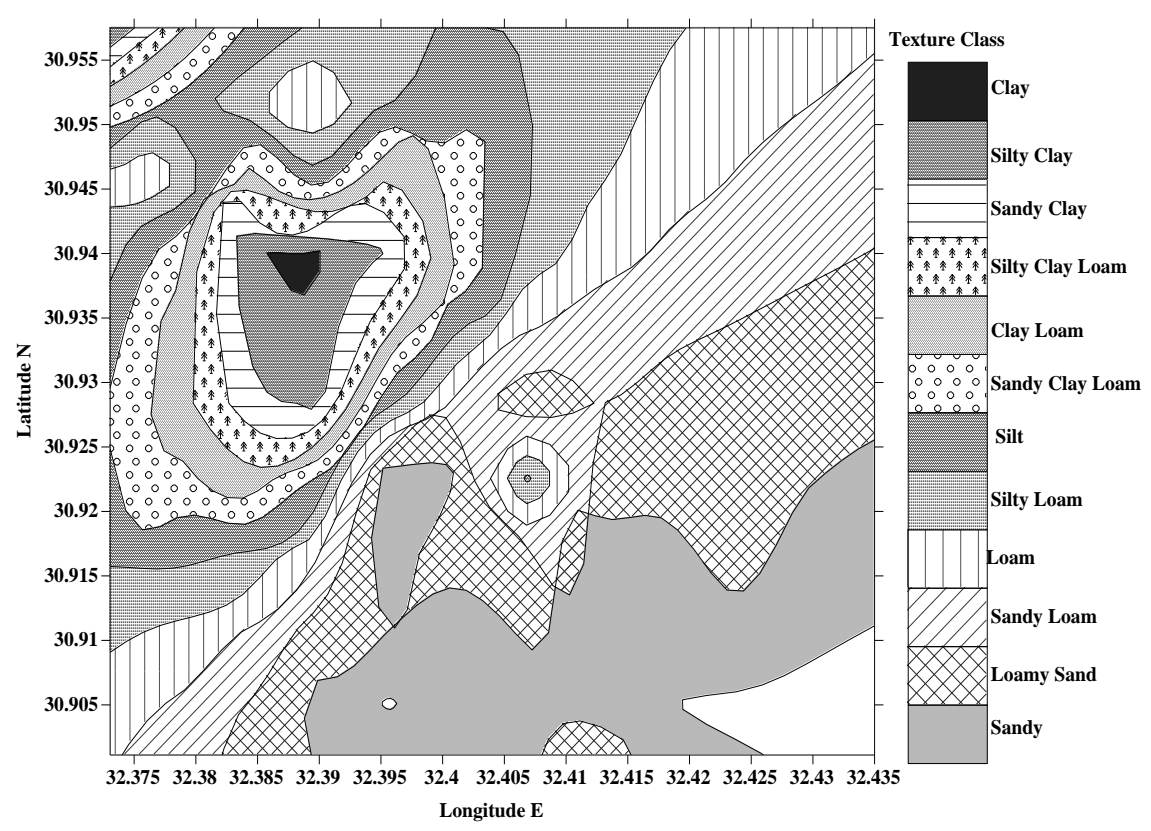

Fig. 1. Contour for texture composition of the soil data set.

Soil $p H$

The $\mathrm{pH}$ is an important parameter which helps in identification of chemical nature of the soil (Shalini et al., 2003) as it measures hydrogen ion concentration in the soil to indicate its acidic and alkaline nature of the soil. In South East El-Qantara, the pH of the soil samples ranged from 7.42 to 8.81 , indicating the existence of a variety of soils that are neutral to alkaline nature (Table 2 and Fig. 2).

\section{Electrical conductivity}

Conductivity, as the measure of current carrying capacity, gives a clear idea of the soluble salts present in the soil. It plays a major role in the salinity of soils. The lesser the EC value, the low will be the salinity value of soil and vice versa.

Egypt. J. Soil Sci. 56, No.3 (2016) 
Even though, soil conductivity is influenced by many factors, high conductivities are usually associated with clay-rich soil and low conductivities are associated with sandy and gravelly soils. This is a result of the shape and physical properties of the particles which make up the soil. In the South East El-Qantara, the EC values varied from 0.65 to $15.22 \mathrm{dS} / \mathrm{m}$, with the highest EC value of $15.2 \mathrm{dS} / \mathrm{m}$ in sample no. 14 and the lowest value of $0.65 \mathrm{dS} / \mathrm{m}$ in sample no. 4 .

Depending on the electrical conductivity of the soil, soil salinity can be classified into five classes. From the results ( Table 3 ) it is clear that the salinity problem is not critical in the South East El-Qantara as the saline criterion is < 0.7 , indicating the good quality of soil Fig. 3 Because, the soluble salts concentration above $4 \mathrm{dS} / \mathrm{m}$ in soil inhibits the seed germination and growth of most commercial crops, which adversely affects the biomass production and economic yield.

TABLE 2. The pH values of soil samples

\begin{tabular}{|c|c|c|c|}
\hline SI & pH value & Range & Sample \% \\
\hline 1 & $6.50-7.00$ & --- & --- \\
\hline 2 & $7.00-7.50$ & $7.42-7.53$ & 2.06 \\
\hline 3 & $7.50-8.00$ & $7.72-8.00$ & 14.43 \\
\hline 4 & $8.00-8.50$ & $8.01-8.81$ & 75.26 \\
\hline 5 & $8.50-9.00$ & $8.55-8.81$ & 8.24 \\
\hline
\end{tabular}

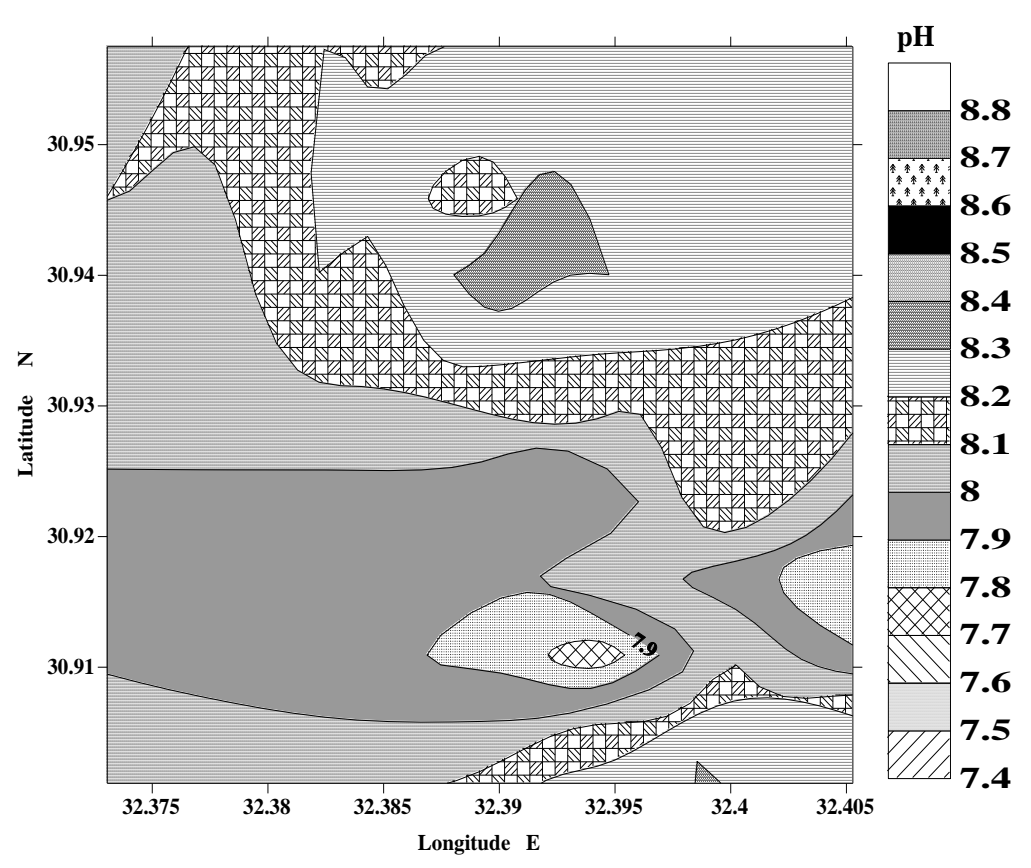

Fig.2. Contour for class of soil reaction $(\mathrm{pH})$

Egypt. J. Soil Sci. 56, No. 3 (2016) 
TABLE 3. Salinity condition and categories of crops tolerance in South East ElQantara

\begin{tabular}{|c|c|c|c|}
\hline EC $(\mathbf{d S} / \mathbf{m})$ & Category & Range & Sample \% \\
\hline$<2.0$ & All crops & $0.65-1.99$ & 63.91 \\
\hline $2.0-4.0$ & Most crops & $2.02-3.94$ & 25.77 \\
\hline $4.0-8.0$ & Salt tolerant crops & $4.02-7.95$ & 8.24 \\
\hline $8.0-16.0$ & Most halophytes & $10.0-15.22$ & 2.06 \\
\hline$>16.0$ & $\begin{array}{c}\text { Unsuitable for most } \\
\text { crop }\end{array}$ & --- & \\
\hline
\end{tabular}

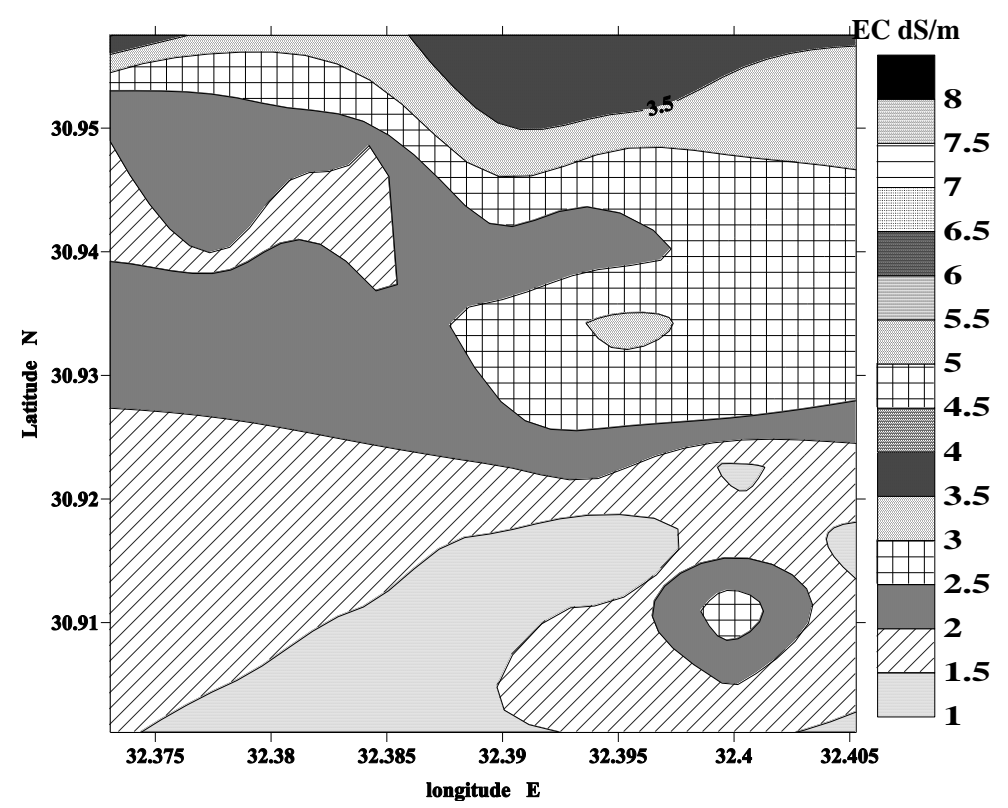

Fig. 3. Contour for class of soil salinity

Organic carbon $(O C)$

The importance of organic matter in the soil is implied in the definition of soil, which recognizes fertility status of the soil, as a unique feature distinguishing soil from the parent rock / other non-fertile soils. It increases the soil fertility / nutrient status and controls erosion and runoff of the soil and water, besides it is a major determinant of improved soil structure, moisture content and general nutrient status of the soil. The percentage of organic carbon of the studied soils ranged from 0.14 to $1.2 \%$ (Fig. 4). Depending on the organic carbon content (\%), the quality of soil could be graded as low, medium and high. In the South East ElQantara, $10.3 \%$ of the samples showed low percent of organic carbon (i.e., OC < 0.40 ). Majority of the soil samples (i.e., $65 \%$ ) appear to possess low to medium percentage of organic carbon content (Table 4) and it is necessary to apply organic manure to these soils.

Egypt. J. Soil Sci. 56, No.3 (2016) 
TABLE 4. Classification of soil quality based on organic carbon content in South East El-Qantara

\begin{tabular}{|c|c|c|c|c|}
\hline SI. No. & OC \% & Rating & Range & Sample \% \\
\hline 1 & $<0.40$ & Low & $0.14-0.38$ & 10.30 \\
\hline 2 & $0.4-0.75$ & Medium & $0.42-0.75$ & 54.65 \\
\hline 3 & $>0.75$ & High & $0.76-1.20$ & 35.05 \\
\hline
\end{tabular}

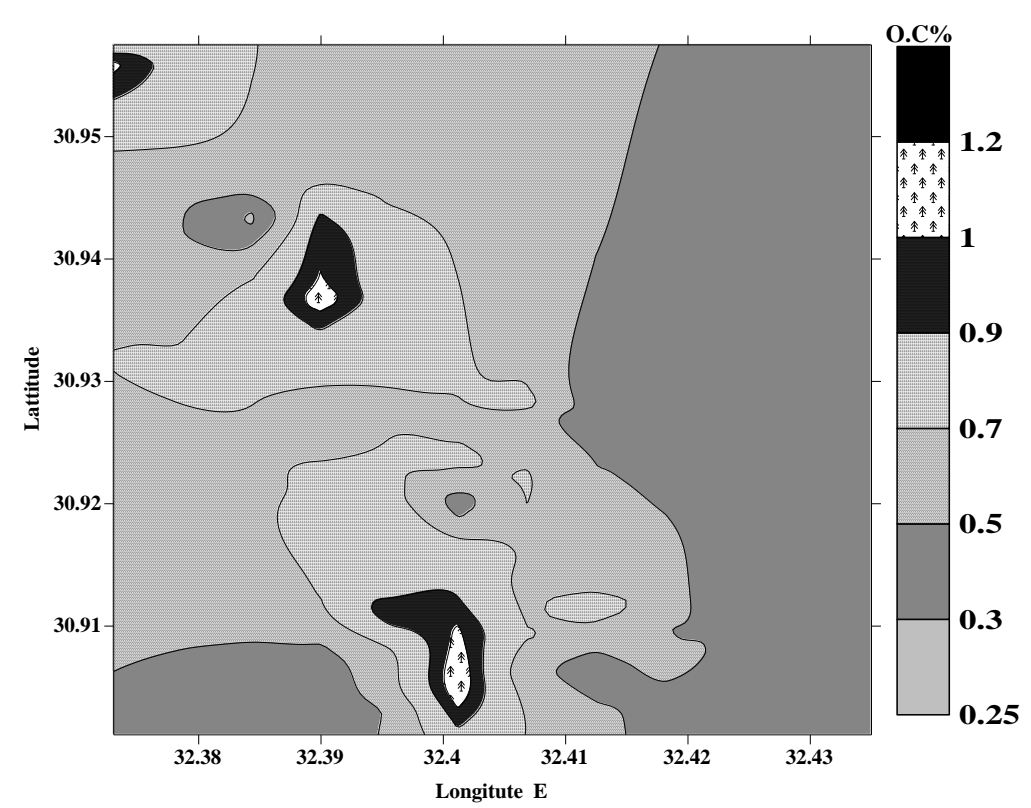

Fig. 4. Contour for organic carbon content in the soil data set

\section{Available nitrogen}

Plants take up nitrogen generally as nitrates under aerobic conditions and as ammonium ions in anaerobic conditions. Nitrogen is most often the limiting nutrient for the plant growth. Nitrogen content is too low $(<272 \mathrm{mg} / \mathrm{kg}$ ) in all soil samples of the studied area (Table 5). All soil samples are having low available nitrogen content, ranging from 4.19 to 46.70 $\mathrm{mg} / \mathrm{kg}$ (Fig. 5) and it is highly recommended to apply organic manure as an important source of nutrient to these soils.

TABLE 5. Contents of available nitrogen in South East El-Qantara soils

\begin{tabular}{|c|c|c|c|c|}
\hline $\begin{array}{c}\text { SI. } \\
\text { No. }\end{array}$ & $\begin{array}{c}\text { Quantity of available N } \\
(\mathbf{m g} / \mathbf{k g})\end{array}$ & Rating & Range & Sample \% \\
\hline 1 & $<272$ & Low & $4.19-46.70$ & 100 \\
\hline 2 & 272 to 554 & Medium & --- & ---- \\
\hline 3 & $>554$ & High & --- & --- \\
\hline
\end{tabular}




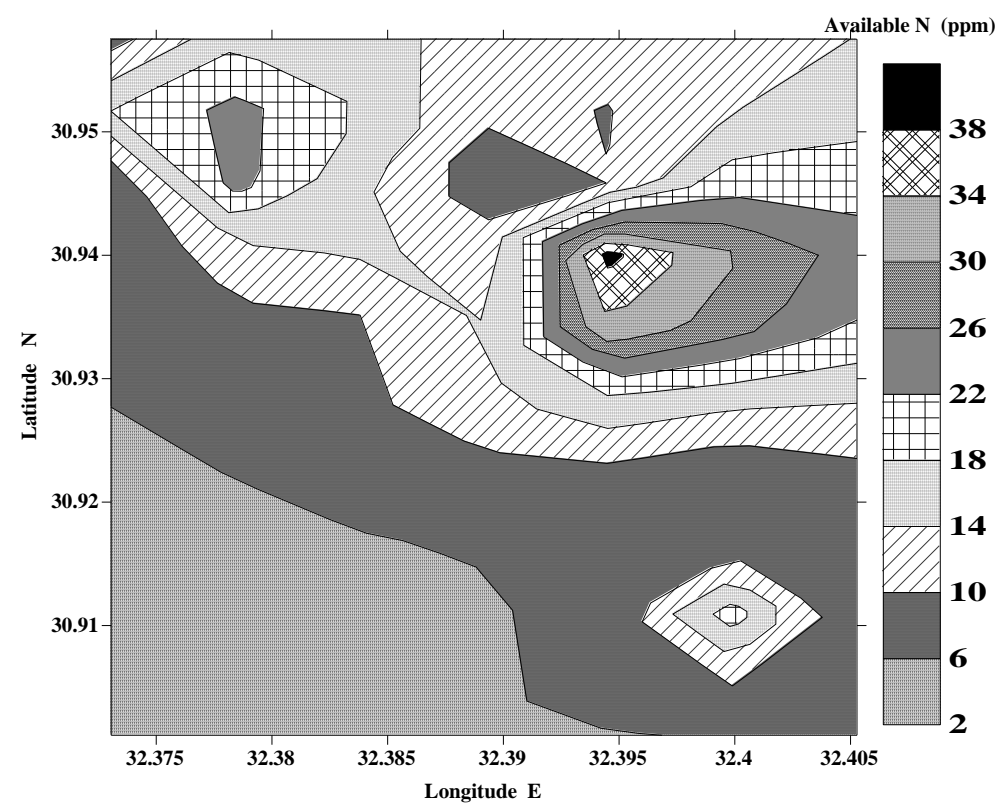

Fig. 5. Contour for distribution of available $\mathbf{N}$ in the studied soils

\section{Available phosphorus}

Phosphorus is the second most important macronutrient available in the biological systems, which constitutes more than $1 \%$ of the dry organic weight. It is also a second most limiting factor often affecting plant growth, which exist in the soil in both organic and inorganic forms. In the South East El-Qantara, the available phosphorus content ranged between 4.1 and $59.2 \mathrm{mg} / \mathrm{kg}$ Fig. 6 and $77.3 \%$ of the soil samples showed low to medium quantity of available phosphorus, while remaining $(22.7 \%)$ had adequate to abundant quantity of available phosphorus (Table 6). Soils having low to medium phosphorus content in the studied area can be supplemented by applying phosphorous rich fertilizers as required for certain crop.

TABLE 6. Contents of available phosphorus in South East El-Qantara soils

\begin{tabular}{|c|c|c|c|c|}
\hline SI. No. & Grade & $\begin{array}{c}\mathbf{P} \\
(\mathbf{m g} / \mathbf{k g})\end{array}$ & Range & Sample \% \\
\hline 1 & Low phosphorus & $<15$ & $4.11-14.63$ & 62.90 \\
\hline 2 & Medium phosphorus & $15-22$ & $15.83-22.70$ & 14.43 \\
\hline 3 & Adequate phosphorus & $23-30$ & $23.06-30.84$ & 12.37 \\
\hline 4 & Abundant phosphorus & $>30$ & $31.80-59.23$ & 10.30 \\
\hline
\end{tabular}

Available potassium (K)

The values of available K varied from 34 to $825 \mathrm{mg} / \mathrm{kg}$ in the South East ElQantara (Fig. 7). Majority of the soil samples in the South East El-Qantara had deficient $(67.01 \%)$, doubtful $(15.46 \%)$ and adequate $(17.53 \%)$ supply of

Egypt. J. Soil Sci. 56, No.3 (2016) 
potassium (Table 7). Soil samples with deficient and doubtful supply of potassium can be enriched with compost containing high content of $\mathrm{K}$.

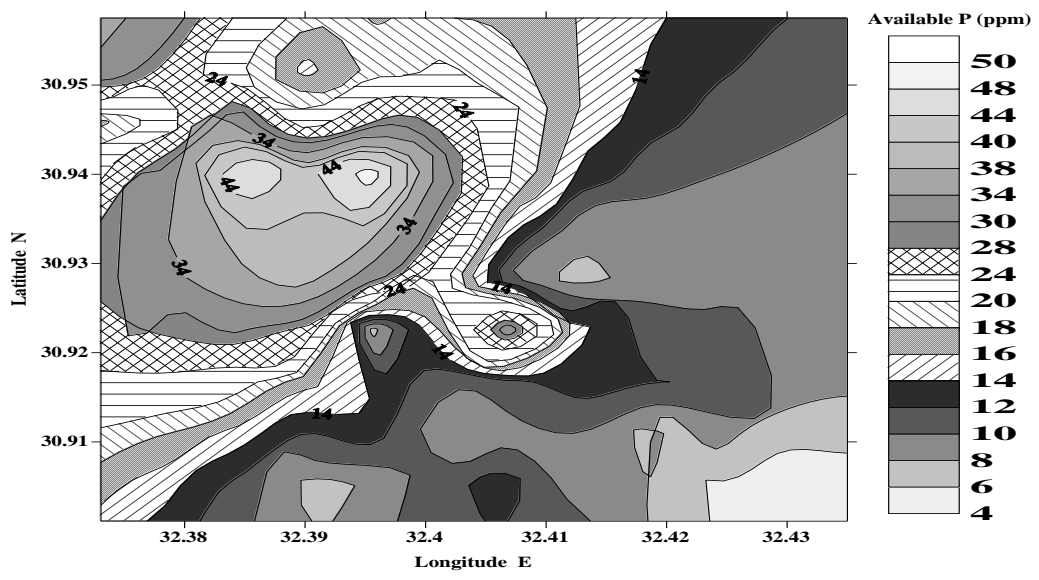

Fig. 6. Contour for distribution of available $P$ in the studied soils

TABLE 7. Contents of available $\mathrm{K}$ in South East EI-Qantara soils

\begin{tabular}{|c|c|c|c|c|}
\hline SI. No. & Supply of available K & $\begin{array}{c}\text { Quantity } \\
(\mathbf{m g} / \mathbf{k g})\end{array}$ & Range & Sample \% \\
\hline 1 & Deficient supply of K & $<113$ & $34-110$ & 67.01 \\
\hline 2 & Doubtful supply of K & 113 to 280 & $113-255$ & 15.46 \\
\hline 3 & Adequate supply of K & $>280$ & $306-825$ & 17.53 \\
\hline
\end{tabular}

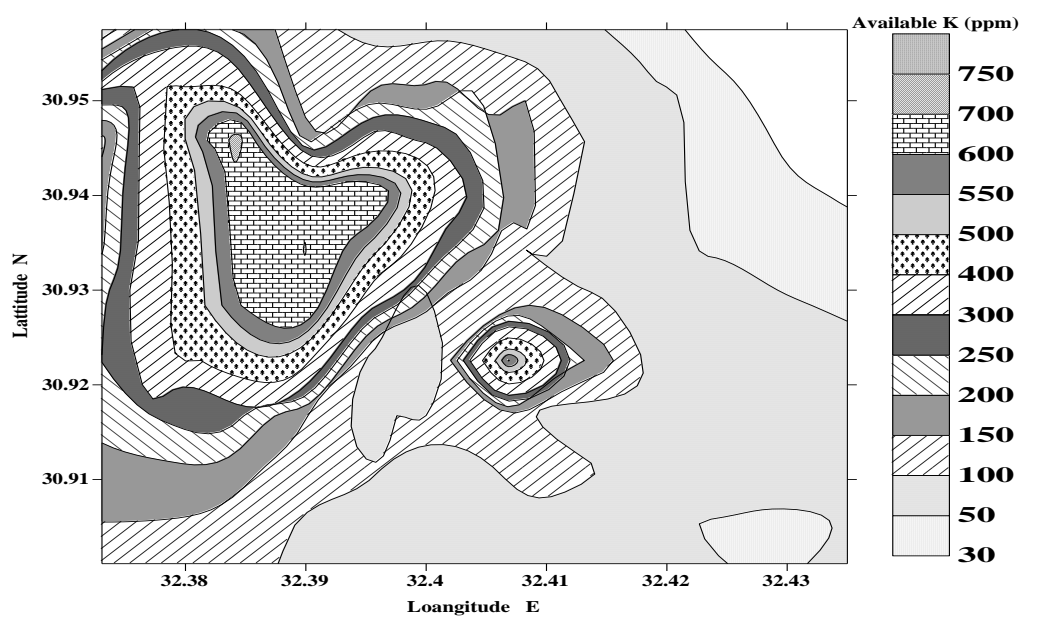

Fig.7. Contour for distribution of available $\mathrm{K}$ in the studied soils.

DTPA- extractable iron

In the South East El-Qantara, the available iron content ranged between 3.96 and $20.22 \mathrm{mg} / \mathrm{kg}$. According to the critical levels reported by Lindsay and 
Norvell (1978), the data in Table 8 and Fig. 8 of DTPA-extractable Fe showed that $11.3 \%$ of the tested soils (11 samples) are suffering $(<4 \mathrm{mg} / \mathrm{kg})$, while $54.6 \%$ (53 samples) are on the margin, and 35.1\% (34 samples) having adequate contents. The margin soils are those sandy in texture. The amount of DTPA extractable Fe as extracted by DTPA solution increased with increasing clay and/or silt content in soils.

TABLE 8. Contents of DTPA extractable iron in South East El-Qantara soils

\begin{tabular}{|c|c|c|c|c|}
\hline SI. No. & Grade & $\begin{array}{c}\text { Fe } \\
(\mathbf{m g} / \mathbf{k g})\end{array}$ & Range & Sample \% \\
\hline 1 & Very low & $0-2$ & --- & -- \\
\hline 2 & Low & $2-4$ & $3.9-4.0$ & 11.34 \\
\hline 3 & Medium & $4-6$ & $4.02-5.86$ & 53.61 \\
\hline 4 & High & $6-10$ & $6.06-9.86$ & 23.71 \\
\hline 5 & Very High & $>10$ & $10.08-20.22$ & 11.34 \\
\hline
\end{tabular}

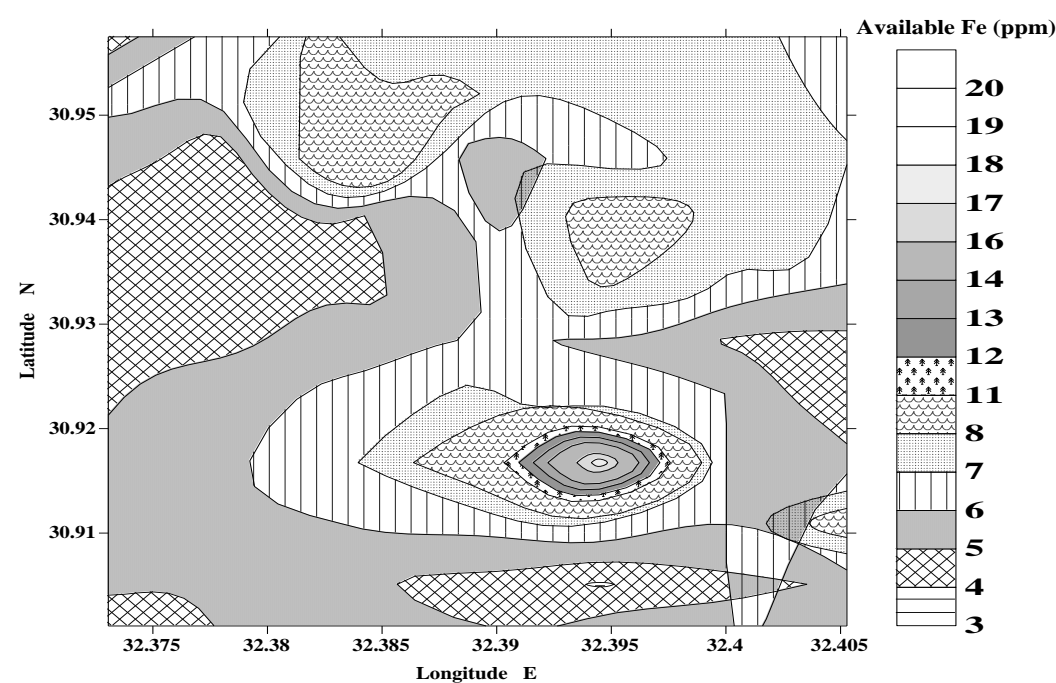

Fig. 8. Contour for distribution of DTPA extractable Fe in the studied soils

DTPA- extractable manganese

Values of DTPA extractable-Mn varied from 1.86 to $18.92 \mathrm{mg} / \mathrm{kg}$, with an average of $6.82 \mathrm{mg} / \mathrm{kg}$. The values of $\mathrm{Mn}$ are mostly higher in soil having high clay or silt content than those characterized by light textures ones. According to the critical levels reported by Lindsay and Norvell (1978) the data in Table 9 and Fig. 9 of DTPA-extractable Mn showed that $13.4 \%$ of the tested soils (13 samples) are moderate, and the remaining $86.6 \%$ soil contained high amounts of DTPA extractable Mn. 
TABLE 9. Contents of DTPA extractable manganese in South East El-Qantara soils

\begin{tabular}{|c|c|c|c|c|}
\hline SI. No. & Grade & $\begin{array}{c}\text { Mn } \\
(\mathbf{m g} / \mathbf{k g})\end{array}$ & Range & Sample \% \\
\hline 1 & Very low & $0-0.5$ & --- & -- \\
\hline 2 & Low & 0.51 .2 & -- & -- \\
\hline 3 & Medium & $1.2-3.5$ & $1.86-3.48$ & 13.40 \\
\hline 4 & High & $3.5-6.0$ & $3.46-5.94$ & 27.84 \\
\hline 5 & Very High & $>6.0$ & $6.10-18.92$ & 58.76 \\
\hline
\end{tabular}

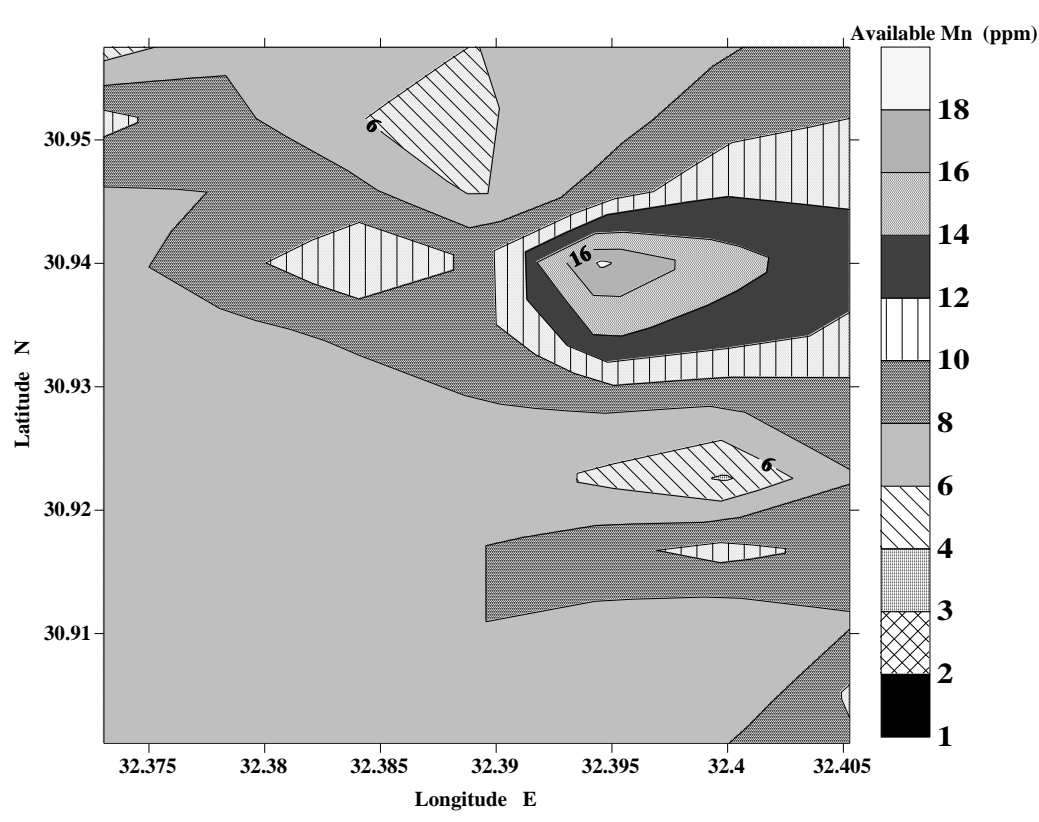

Fig. 9. Contour for distribution of DTPA extractable Mn in the studied soils

DTPA- extractable zinc

Values of DTPA- extractable Zn (Table 10) in the studied soils ranged from 0.32 to $2.72 \mathrm{mg} / \mathrm{kg}$, with an average of $0.78 \mathrm{mg} / \mathrm{kg}$. About $80.4 \%$ of the soil samples were $\mathrm{Zn}$ deficient $(<1.0 \mathrm{mg} / \mathrm{kg})$, and $19.6 \%$ contained moderate amount of DTPA extractable Zn (1.0 - $3.0 \mathrm{mg} / \mathrm{kg})$ (Fig. 10).

TABLE 10. Contents concentration of available zinc in South East El-Qantara soils

\begin{tabular}{|c|c|c|c|c|}
\hline SI. No. & Grade & $\begin{array}{c}\mathbf{Z n} \\
(\mathbf{m g} / \mathbf{k g})\end{array}$ & Range & Sample \% \\
\hline 1 & Very low & $<0.50$ & $0.32-0.50$ & 36.08 \\
\hline 2 & Low & $0.50-1.0$ & $0.52-0.98$ & 44.33 \\
\hline 3 & Medium & $1.0-3.0$ & $1.02-2.72$ & 19.59 \\
\hline 4 & High & $3.0-5.0$ & -- & -- \\
\hline 5 & Very High & $>5.0$ & -- & -- \\
\hline
\end{tabular}

Egypt. J. Soil Sci. 56, No. 3 (2016) 


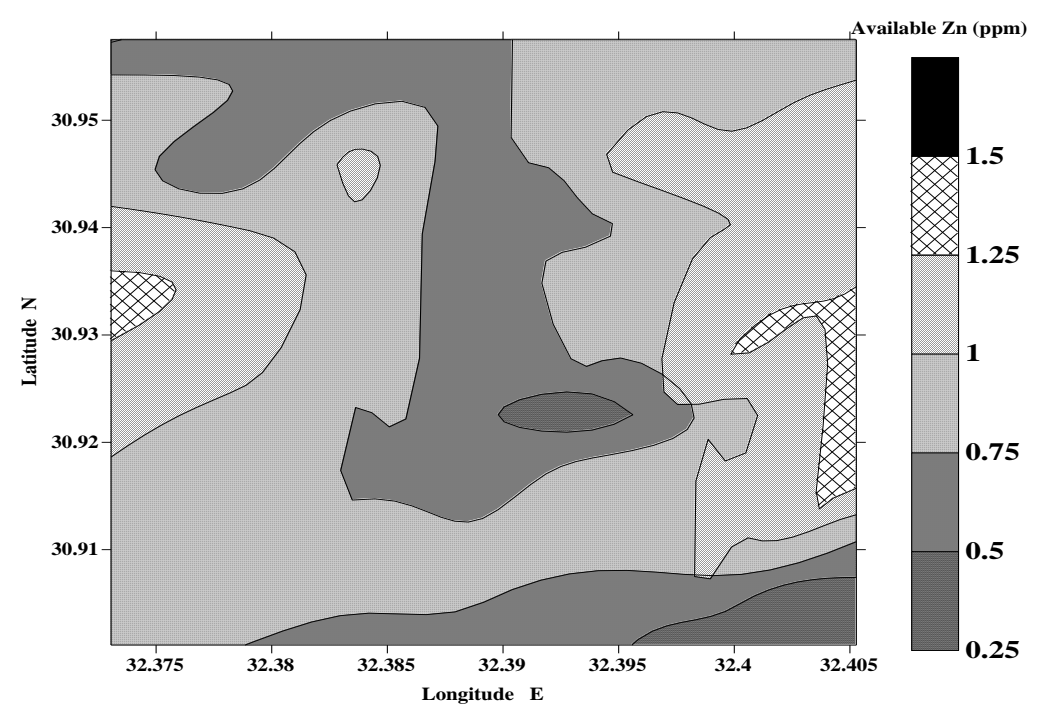

Fig. 10. Contour for distribution of DTPA extractable $\mathrm{Zn}$ in the studied soils

\section{DTPA- extractable copper}

The values of DTPA- extractable $\mathrm{Cu}$ of studied soils ranged from 0.15 to $0.96 \mathrm{mg} / \mathrm{kg}$, with an average of $0.45 \mathrm{mg} / \mathrm{kg}$. About $24.7 \%$ of the soils had low available $\mathrm{Cu}$ content, $68.0 \%$ contained moderate amount of DTPA extractable $\mathrm{Cu}$, and the remaining $70.2 \%$ of soils contained high amounts of DTPA extractable $\mathrm{Cu}$ (Table 11) and (Fig. 11).

\section{Fertility status of soils}

\section{Nutrient index}

To evaluate the soil fertility status in the South of East El-Qantara, different indices like soil reaction index, salt and nutrient index with index respect to organic carbon, available phosphorus and available $\mathrm{K}$ were calculated based on the specific rating chart. Table 12 presented nutrient index with range and remarks

TABLE 11. Contents of DTPA extractable copper in South East El-Qantara soils

\begin{tabular}{|c|c|c|c|c|}
\hline SI. No. & Grade & $\begin{array}{c}\mathrm{Cu} \\
(\mathrm{mg} / \mathrm{kg})\end{array}$ & Range & Sample \% \\
\hline 1 & Very low & $<0.10$ & -- & -- \\
\hline 2 & Low & $0.10-0.30$ & $0.15-0.30$ & 24.74 \\
\hline 3 & Medium & $0.30-0.80$ & $0.32-0.80$ & 68.04 \\
\hline 4 & High & $0.80-3.0$ & $0.85-0.96$ & 7.22 \\
\hline 5 & Very High & $>3.0$ & -- & -- \\
\hline
\end{tabular}




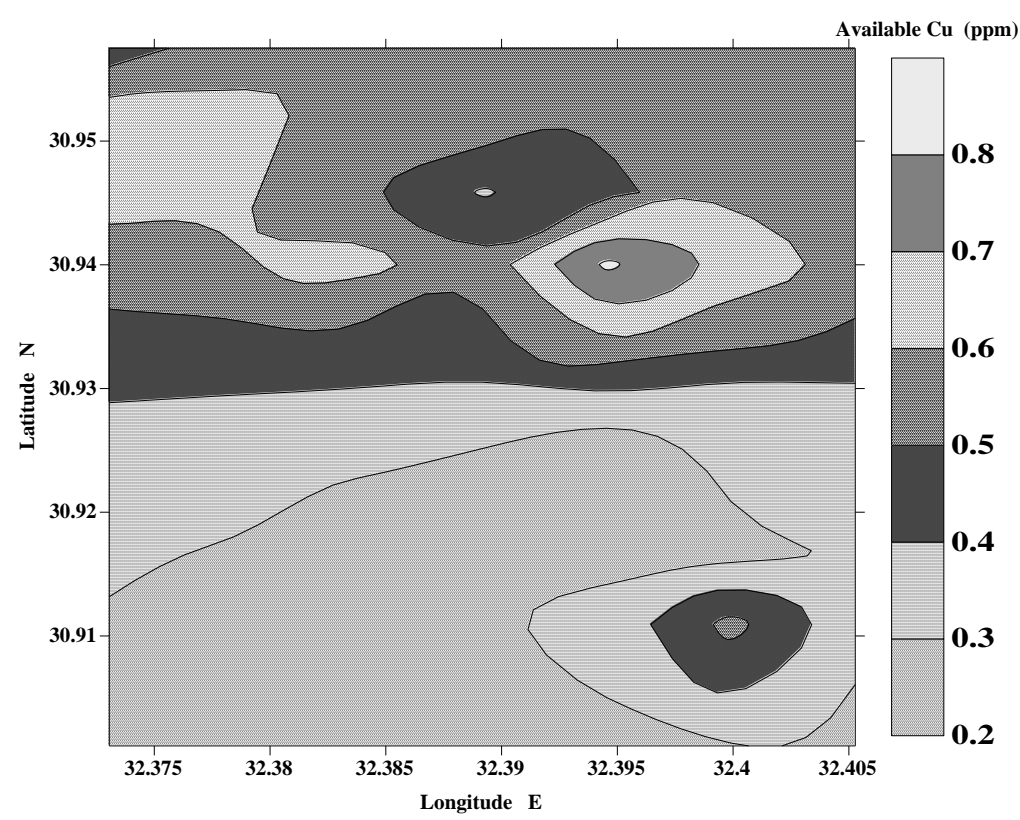

Fig. 11. Contour for distribution of DTPA extractable $\mathrm{Cu}$ in the studied soils

TABLE 12. Nutrient index with range and remarks

\begin{tabular}{|c|c|c|}
\hline Nutrient Index & Range & Remarks \\
\hline I & $<1.67$ & Low \\
\hline II & $1.67-2.33$ & Medium \\
\hline III & $>2.33$ & High \\
\hline
\end{tabular}

The nutrient index in soil was evaluated for the soil samples analyzed using the following formula according to Ravikumar and Somashekar (2013).

Nutrient Index $=[(1 \mathrm{x}$ no. of samples in low category $)+(2 \times$ no. of samples in medium category $)+(3 \times$ no. of samples in High category $)] /$ Total number of samples

In the South of East El-Qantara soils, the overall quality of soil in the studied area appears to be very fertile except for certain parameters. Soil $\mathrm{pH}$ ranged between 7.42 and 8.81, and all the samplers belong to soil reaction index IV, which indicate the neutral to slight alkaline range. The electrical conductivity of the soil samples ranged between of 0.65 and $15.22 \mathrm{dS} / \mathrm{m}$ which indicate the nonsalinity to salinity range (i.e., salt index-I and III) category. Organic carbon content ranged from 0.14 to 1.2 and majority of the samples indicate medium to high range as per the nutrient index. The available phosphorus values (4.11-59.23 $\mathrm{mg} / \mathrm{kg}$ ) are in low to high range, whereas the available nitrogen values (4.19- 
$46.70 \mathrm{mg} / \mathrm{kg}$ ) belong to low range. It is possible to classify nutrient status of the particular area and classify each nutrient level (i.e., low, medium or high) based on a rating chart using the results and nutrient indices. Based on the criteria given in Table 2, the soils of South East El-Qantara were categorized into medium-lowmedium-low (MLML) category based on OC, available $\mathrm{N}$, available $\mathrm{P}$ and available $\mathrm{K}$ concentrations, respectively (Table 13).

TABLE 13. Nutrient Index values for the soil samples of South East El-Qantara .

\begin{tabular}{|c|c|c|}
\hline Characteristics & Nutrient index values & Remarks \\
\hline Organic carbon (OC) & 1.938 & Medium \\
\hline Available N & 1.000 & Low \\
\hline Available P & 1.835 & Medium \\
\hline Available K & 1.485 & Low \\
\hline
\end{tabular}

\section{References}

Adolfo, C.C., Klaudia, O.L., Jorge, E.B. et al. (2007) Exploring the effect of changes in land use on soil quality on the eastern slope of the Cofre de Perote Volcano (Mexico). Forest Ecology and Management, 248, 174-182

Brejda, J.J., Moorman, T.B., Karlen, D.L. et al. (2000) Identification of regional soil quality factors and indicators: I Central and southern high plains. Soil Science Society of America Journal, 64, 2115-2124

Cambardella, C.A., Moorman, T.B. and Novak, J.M. (1994) Field-scale variability of soil properties in central Iowa soils. Soil Science Society of America Journal, 58, $1501-1511$

Carter, M.R., Andrews, S.S. and Drinkwater, L.E. (2004) Systems approaches for improving soil quality. In: Managing Soil Quality: Challenges in Modern Agriculture (Schjonning, P., Elmholt, S., Christensen, B.T., Ed.). 261-281, CABI International, Wallingford, UK

Dhank, W.C. and Johson, G. V. (1990) Testing soils for available nitrogen. In: Soil Testing and Plant Analysis. $3^{\text {rd }}$ ed., SSSA book serics No. 3, R.L. Westerman (Ed). Madison, WI: Soil Sci. Soc. of Am. J., 127-139.

Jenny, H. (1980) The Soil Resource: Origin and Behavior. Ecological Studies, vol. 37. Springer-Verlag, New York, USA

Juo, ASR and Manu, A. (1996) Chemical dynamics in slash-and-burn agriculture. Agriculture, Ecosystems and Environment, 58, 49-60

Karlen, D.L., Ditzler, C.A. and Andrews, AS. (2003) Soil quality: Why and how? Geoderma, 114, 145-156

Karlen, D.L., Mausbach, M.J., Doran, J.W., et al. (1997) Soil quality: A concept, definition, and framework for evaluation. Soil Science Society of America Journal, 61, $4-10$

Egypt. J. Soil Sci. 56, No.3 (2016) 
Katyal, J.C. (2003) Soil fertility management- A key to prevent desertification. Journal of the Indian Society of Soil Science, 51, 378-387

Klute, A. (1986) Methods of Soil Analysis, part 1, Physical and Mineralogical Methods. Am. Soc. of Agron. And am. Soc. Soil Sci. Methods. Madison, Wisconsin, USA

Lindsay, W.L. and Norvell, W.A. (1978) Development of a DTPA soil test for zinc, iron, manganese, and copper. Soil Sci. Soc. of Am. J., 42, 421-428.

Page, A.L., Miller, R.H. and Keeny, D. R. (1982) Methods of Soil Analysis, Part 2. Chemical and Microbiological Properties $2^{\text {nd }}$ ed. Am. Soc. of Agron., Madison, Wisconsin, USA

Quine, T.A. and Zhang, Y. (2002) An investigation of spatial variation in soil erosion, soil properties and crop production within an agricultural field in Devon. U.K. Journal of Soil and Water Conservation, 57, 50-60

Ravikumar, P. and Somashekar, R. K. ( 2013) Evaluation of nutrient index using organic carbon, available $\mathrm{P}$ and available $\mathrm{K}$ concentrations as a measure of soil fertility in Varahi River basin, India. Proceedings of the International Academy of Ecology and Environmental Sciences, 2013, 3(4), 330-343

Shalini Kulshrestha, Devenda, H.S. and Dhindsa, S.S. (2003) Studies on causes and possible remedies of water and soil pollution in Sanganer town of Pink City. Indian Journal of of Environmental Sciences, 7(1), 47-52

Stevenson F.S. (1982) Organic matter and nutrient availability. In: Non-symbiotic Nitrogen Fixation and Organic Matter in the Tropics. Trans. $12^{\text {th }}$ Int. Cong. Soil Sci. 137-151, New Delhi, India

USDA-ERS. (1997) Agricultural Resources and Environmental Indicators 1996-1997. Agricultural Handbook, 712. U.S. Gov. Print. Office, Washington DC, USA

Vieira S.R. and Paz Gonzalez A. (2003) Analysis of the spatial variability of crop yield and soil properties in small agricultural plots. Bragantia (Campinas), 62, 127-138

Warren, A. and Agnew, C. (1988) An Assessment of Desertification and Land Degradation in Arid and Semi Arid Areas. Drylands Farming, Ecology and Conservation Unit, University College, London, UK

Zhang, W.J. and Zhang, X.Y. (2007) A forecast analysis on fertilizers consumption worldwide. Environmentla Monitoring and Assessment, 133: 427-434.

(Received 2/8/2015;

accepted $1 / 10 / 2015)$ 


\section{تقييم دليل المغذيات كمؤشر لتقدير خصوبة التربة في جنوب \\ القتطرة شرق ، شمال سيناء}

$$
\begin{aligned}
& \text { محمد فتحي ابو يوسف ، "محم الثربينى حسين و "أمل لطفى عبد اللطيف }
\end{aligned}
$$

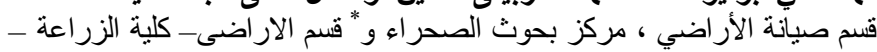

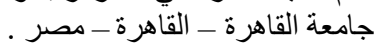

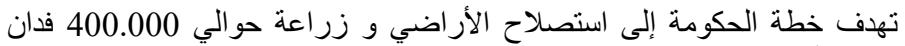

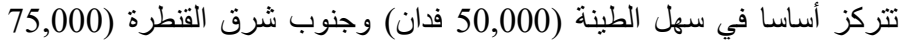

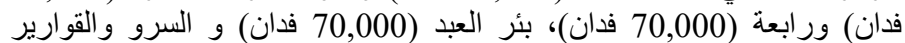

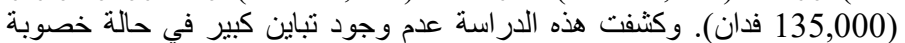

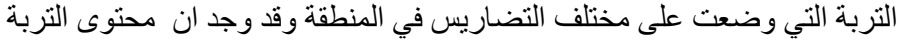

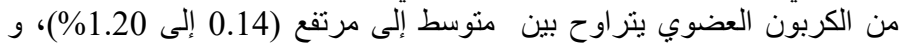

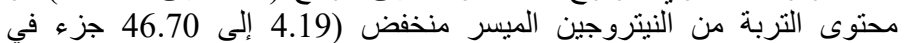

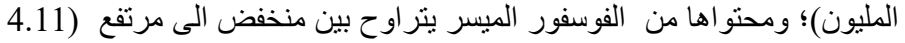

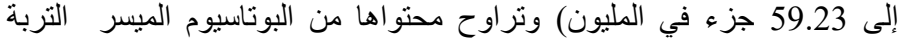

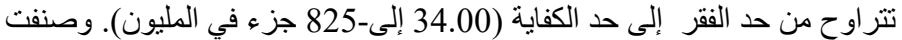

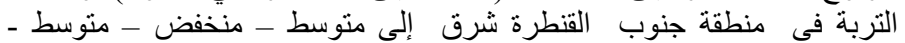

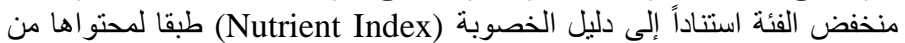
المادة العضويه و وتيسر النتروجين و الفوسفور و البوتاسيوم ، على الترتيب. 
